\section{Amplificação de mRNA de Tireoglobulina no Sangue de Pacientes Com Carcinoma Diferenciado da Tireóide: Qual o Seu Verdadeiro Significado?}

\section{RESUMO}

Apesar do excelente prognóstico, aproximadamente 20-40\% dos pacientes com carcinoma diferenciado da tireóide (CDT) evoluem com recidiva tumoral e o prognóstico está relacionado principalmente à detecção precoce da doença. Desta forma, o acompanhamento permanente dos pacientes com exames sensiveis é fundamental. A tireoglobulina (Tg) sérica já demonstrou importância como marcador de recidiva. Entretanto, sua dosagem apresenta ainda algumas dificuldades, como a interferência com anticorpo anti-Tg, e a sensibilidade dependente do nível de TSH. A amplificação de mRNA tumor-específico extraído a partir de células neoplásicas na corrente sangüínea apresentou resultados iniciais promissores. No entanto, após quase uma década de estudo da detecção do mRNA de Tg no sangue, ainda não foi estabelecida sua real contribuição no acompanhamento dos pacientes com CDT. Após análise crítica dos estudos publicados, verifica-se a enorme diversidade de protocolos empregados e resultados conflitantes. Desta forma, até o momento, a amplificação de mRNAs tireóideespecíficos não é superior à dosagem de Tg sérica existente. A possibilidade de transcrição ilegítima e splicing alternativo são fatores que podem interferir com a especificidade do método. (Arq Bras Endocrinol Metab 2006;50/3:427-435)

Descritores: Câncer de tireóide; Tireoglobulina; mRNA de tireoglobulina

\begin{abstract}
Thyroglobulin mRNA Amplification in Peripheral Blood of Patients With Differentiated Thyroid Carcinoma: What Does It Really Mean?

Despite the excellent prognosis, differentiated thyroid carcinoma (DTC) may recur in $20-40 \%$, and prognosis is particularly related to early detection of recurrent disease. Therefore, long-term follow-up with sensitive tests is need. Serum thyroglobulin (Tg) has an established role as a tumor marker of relapse. However, there are technical limitations of Tg immunoassays, in special, the interference of anti-Tg antibodies and the method sensitivity is dependent on TSH stimulation. Detection of circulating malignant cells by amplification of tumor-specific mRNA showed initial promising results. However, almost one decade of studies of Tg mRNA detection in peripheral blood, its real contribution for DTC follow-up had not yet been established. After a critical analysis of published data, it is clear that there are many protocol differences and conflicting results. Therefore, it seems that amplification of thyroidspecific mRNAs is not superior to sensitive Tg assays and illegitimate transcription and alternative splicing of Tg are factors that may influence mRNA test specificity. (Arq Bras Endocrinol Metab 2006;50/3:427-435)
\end{abstract}

Keywords: Thyroid cancer; Thyroglobulin; Thyroglobulin mRNA artigo original

\author{
Sabrina Mendes Coelho \\ Mário Vaisman \\ Denise Pires de Carvalbo
}

Serviço de Endocrinologia do

Hospital Universitário Clementino Fraga Filho (SMC, $M V)$ e Laboratório de Fisiologia Endócrina do Instituto de Biofísica Carlos Chagas Filho (DPC), Universidade Federal do $R$ io de Janeiro, $R J$.
Recebido em 04/07/05

Revisado em 06/03/06 Aceito em 23/03/06 
O CARCINOMAS DIFERENCIADOS DA TIREÓIDE (CDT), papilífero e folicular, estão entre as neoplasias malignas com melhor índice de cura. A taxa de sobrevida em 20 anos é de $95 \%$ para o carcinoma papilífero e de 70 a $80 \%$ para o folicular (1). No entanto, alguns pacientes apresentam alto risco de recorrência tumoral, ou mesmo de morte, e o prognóstico é afetado por fatores relacionados ao paciente, ao tratamento e à própria doença. A recidiva tumoral, local ou à distância, não é infreqüente, podendo ocorrer até algumas décadas após o diagnóstico (2), evidenciando a necessidade de acompanhamento permanente dos pacientes com CDT.

A forma clássica de avaliar a presença de recorrência tumoral é o acompanhamento da tireoglobulina (Tg) sérica e a realização de cintilografia de corpo inteiro com iodo radioativo (PCI). A ultra-sonografia (USG) cervical também vem se afirmando como método diagnóstico importante para a detecção de recorrência cervical, com sensibilidade superior à $\mathrm{Tg}$ sérica e à $\mathrm{PCI}(3)$.

Em pacientes com CDT, espera-se que a $\mathrm{Tg}$ sérica torne-se indetectável após tratamento ablativo (tireoidectomia total ou subtotal alargada complementada com iodo radioativo). Nesta situação, qualquer nível detectável de Tg pode indicar persistência ou recorrência da doença maligna. Vários estudos têm confirmado o importante papel da $\mathrm{Tg}$ sérica como marcador tumoral no acompanhamento de pacientes com CDT (4-6). Entretanto, o ensaio da Tg apresenta ainda alguns dilemas técnicos, em especial a interferência com anticorpo anti- $\mathrm{Tg}$, presente em cerca de 15 a $25 \%$ dos pacientes com CDT (7-9), e a sensibilidade dependente do nível de TSH. A administração de TSH recombinante precedendo a dosagem de $\mathrm{Tg}$ sérica é interessante, pois aumenta a síntese de $\mathrm{Tg}$ pelos tireócitos, melhorando a sensibilidade do método, e evita os sintomas indesejáveis do hipotireoidismo. No entanto, o alto custo desta substância dificulta seu emprego no seguimento dos pacientes com CDT.
$\mathrm{Na}$ tentativa de melhorar o acompanhamento de pacientes com câncer, diagnosticando precocemente a recidiva, esforço tem sido realizado para o desenvolvimento de métodos alternativos. A amplificação de mRNA tumor específico extraído a partir de sangue parece ser útil em detectar células neoplásicas na corrente sangüínea (10-12). Na década de 90, iniciouse a avaliação da pesquisa de mRNA de Tg em amostra de sangue de pacientes com CDT, com resultados iniciais promissores (13-15).

\section{Dificuldades técnicas da dosagem de tireoglobulina sérica}

A Tg é uma proteína sintetizada exclusivamente pelas células foliculares da tireóide. É codificada por um gene de pelo menos $300 \mathrm{~kb}$, contendo 48 exons e localizado no cromossomo 8 (16-18). O produto final é uma glicoproteína de $660 \mathrm{kDa}$, formada por 2 subunidades idênticas, unidas por ligação não-covalente. A $\mathrm{Tg}$ pode apresentar-se de forma heterogênea em decorrência de processamento alternativo (splicing alternativo) do seu mRNA.

Por muitos anos acreditava-se que a $\mathrm{Tg}$ era encontrada exclusivamente na glândula tireóide. A partir da década de 40 surgiram relatos de detecção de Tg no sangue (19), mas foram Van Herle e cols. (20) que estabeleceram o primeiro método clinicamente útil para detectar a $\mathrm{Tg}$, o radioimunoensaio (RIE) utilizando anticorpo policlonal de coelho. $\mathrm{Na}$ década de 80 , os ensaios radioimunométricos (IRMAs) com anticorpo monoclonal tornaram-se disponíveis.

Atualmente, existem 4 imunoensaios disponíveis para a dosagem da Tg: RIE (com duplo ou único anticorpo), IRMA, ELISA (enzyme-linked immunosorbent assay) e ICMA (imunoquimioluminescência). Destes, o RIE com duplo anticorpo, IRMA e ICMA são as técnicas de escolha.

Vários fatores podem afetar a acurácia do ensaio de $\operatorname{Tg}$ (tabela 1), podendo ser divididos em fatores ensaio-dependentes e independentes (21). Dentre os

Tabela 1. Dificuldades técnicas da dosagem de tireoglobulina sérica.

\begin{tabular}{ll}
\hline \multicolumn{1}{c}{ Anticorpo anti-Tg } \\
\hline Fatores ensaio-independentes & \multicolumn{1}{c}{ Fatores ensaio-dependentes } \\
\hline Sensibilidade dependente do nível de TSH & Falta de padronização internacional \\
Niveis extremamente elevados de Tg sérica & Especificidades diferentes dos anticorpos \\
(efeito gancho) & utilizados \\
Anticorpo heterofílico & Falta de precisão interensaio \\
Gamapatia monoclonal & Falta de precisão intraensaio \\
Doença renal terminal & Sensibilidade funcional sub-ótima \\
\hline
\end{tabular}

Anti-Tg: anticorpo anti-tireoglobulina, Tg: tireoglobulina.

Baseado em Torréns e cols., 2001 (ref. 21). 
fatores dependentes do ensaio destacam-se falta de padronização internacional, especificidades diferentes dos anticorpos utilizados pelos diferentes kits comerciais, falta de precisão interensaio e intraensaio, sensibilidade funcional sub-ótima e variante de $\mathrm{Tg}$ não reconhecida pelo anticorpo utilizado no método. Com relação aos fatores ensaio-independentes, destacam-se anticorpo anti-Tg, sensibilidade dependente do nível de TSH, efeito gancho, anticorpo heterofílico, além da gamapatia monoclonal e doença renal terminal.

Anticorpo anti-Tg permanece como o principal fator de erro na dosagem de Tg sérica, uma vez que aproximadamente 15 a $25 \%$ dos indivíduos com CDT apresentam anticorpo anti- $\mathrm{Tg}$ (7-9), prevalência esta mais elevada que na população geral. É importante salientar que o grau de interferência não é proporcional ao título do anticorpo e que nenhum método está totalmente livre desta interferência. $\mathrm{Na}$ presença do auto-anticorpo, o RIE geralmente determina falsa elevação da $\mathrm{Tg}$, ao passo que IRMA e ELISA podem subestimar. Desta forma, recomenda-se screening de anticorpo anti-Tg em todo paciente com CDT. Infelizmente, vários laboratórios ainda utilizam teste de hemaglutinação para detecção de auto-anticorpo, que sabidamente apresenta baixa sensibilidade. A discordância entre o nível de Tg medida por RIE e IRMA pode funcionar como um indicador sensível da interferência do anticorpo (8). Uma alternativa é o teste de recuperação, que consiste em adicionar uma quantidade conhecida de $\mathrm{Tg}$ ao soro e medir posteriormente a recuperação: se $<80 \%$ sugere interferência do anticorpo e se $>80 \%$ diminui a possibilidade de interferência. Entretanto, a acurácia deste teste não é alta e, portanto, o mesmo não deve ser utilizado para validar a medida da $\mathrm{Tg}$ sérica $(22)$.

A $\mathrm{Tg}$, quando em nível bastante elevado (10 a 10.000 vezes a faixa superior de detecção), pode ser falsamente detectada em nível normal ou mesmo baixo. Este fenômeno é conhecido como efeito gancho e é exclusivo dos ensaios com duplo anticorpo, como o IRMA e RIE. Neste caso, a diluição do soro é recomendada.
Ao contrário do anticorpo anti- $\mathrm{Tg}$, a interferência do anticorpo heterofílico não é habitualmente reconhecida pelos laboratórios e clínicos. Quando presente, este anticorpo resulta em teste falso positivo (23). Como alguns pacientes são tratados com base na elevação da $\mathrm{Tg}$ sérica, a não identificação do anticorpo heterofilico pode resultar em tratamento desnecessário.

Uma vez na circulação, a meia-vida da Tg é de 3 a 65 horas, dependendo do grau de modificações pós-traducionais (24), e a sua metabolização é feita primariamente pelo fígado. $\mathrm{O}$ nível sérico da $\mathrm{Tg}$ depende de 2 fatores principais: o volume tireoideano e o nível de TSH.

\section{Volume tireoideano}

Em geral, quanto maior a massa de tecido tireoideano remanescente (normal ou neoplásico) maior o nível de Tg sérica. Desta forma, nos pacientes submetidos à terapia ablativa (cirurgia + dose ablativa de $\left.{ }^{131} \mathrm{I}\right)$ a $\mathrm{Tg}$ sérica permanece indetectável numa maior proporção de casos $(98 \%$ x $50 \%)$, em relação aos pacientes tratados de forma mais conservadora (tabela 2).

\section{Nível de TSH}

Como o TSH é um importante estimulador da função tireoideana e mesmo células neoplásicas mantêm expressão de seu receptor, é esperado que o nível de Tg sérica varie de acordo com a concentração de TSH (tabela 2). Desta forma, ao interpretar o valor da Tg deve-se sempre avaliar o nível de TSH.

Cerca de $20 \%$ dos pacientes com metástases para linfonodo e $5 \%$ dos pacientes com pequenas metástases à distância apresentam $\mathrm{Tg}$ indetectável durante terapia supressora de TSH. Esta percentagem cai para 10 e menos de $1 \%$, respectivamente, quando induzido o hipotireoidismo (25).

Outro fator importante para a determinação do nível de Tg sérica é a capacidade intrínseca do tumor de sintetizar e secretar esta glicoproteína. Este fator pode ser avaliado através da determinação pré-operatória da $\operatorname{Tg}$ sérica $(5)$.

Desta forma, observa-se que, apesar da Tg sérica ser um marcador tumoral bastante útil no acompa-

Tabela 2. Detecção da Tg sérica de acordo com o tipo de tratamento e o nível de TSH.

\begin{tabular}{lcc}
\hline & \multicolumn{2}{c}{ \% Pacientes com Tg sérica indetectável } \\
\cline { 2 - 3 } & TSH suprimido & Em hipotireoidismo \\
\hline Cirurgia + ablação com ${ }^{131}$ & $98 \%$ & $90 \%$ \\
Tireoidectomia (total ou subtotal) & $93 \%$ & $80 \%$ \\
Lobectomia unilateral & $50 \%$ & $\sim 0 \%$ \\
\hline Bas
\end{tabular}

Baseado em Schlumberger e Pacini, 1999 (26). 
nhamento pós-operatório, resultados falso-negativos ocorrem (Tg indetectável em vigência de persistência ou recorrência tumoral). Estes casos são geralmente explicados pela menor sensibilidade do exame durante terapia supressora de TSH, pela interferência com anticorpo anti-Tg ou ainda pela desdiferenciação tumoral. Na tentativa de superar estas dificuldades, esforço tem sido realizado para o desenvolvimento de métodos alternativos de investigação.

\section{RNA mensageiro da Tg como possível marcador tumoral}

O conceito de detecção molecular altamente sensível de células tumorais na corrente sangüínea foi descrito no início da década de 90 para tumores sólidos, como carcinoma de próstata (10), neuroblastoma (27) e carcinoma de mama (28). Especialmente no câncer de próstata, a detecção por RT-PCR de células neoplásicas no sangue parecia preceder a elevação dos demais marcadores séricos, favorecendo ao diagnóstico mais precoce da recidiva (29).

No primeiro estudo de mRNA de Tg no acompanhamento de pacientes com CDT, Ditkoff e cols. (13) conseguiram detectar por RT-PCR este mRNA em todos os 9 pacientes com doença metastática e em menos de 10\% (7 de 78) dos pacientes sem metástase. Neste grupo, a detecção do mRNA de Tg foi mais freqüente naqueles com história prévia de metástase ( 5 de 22) do que naqueles sem história de metástase (2 de 56). Nos voluntários normais e nos pacientes com doença benigna não foi vista amplificação. Estes resultados iniciais sugeriram que a presença na circulação sangüínea do mRNA de Tg poderia representar doença tireoideana disseminada via hematogênica.

Posteriormente, Tallini e cols. (14) conseguiram detectar mRNA de Tg e tireoperoxidase (TPO) em $54,2 \%$ dos indivíduos em acompanhamento de CDT, incluindo 5 de 8 pacientes sem evidência de doença no momento do exame. Entretanto, 4 destes 5 casos apresentaram invasão extratireoideana ou metástase para linfonodo no momento da cirurgia. Já a amplificação do mRNA de RET/PTC 1 foi observada em apenas 1 dos 18 pacientes com carcinoma papilífero e em nenhum paciente com doença benigna. Os mRNA de Tg e de TPO foram também detectados em $10 \%$ (2 de 20) dos pacientes com doença tireoideana benigna. No entanto, no pós-operatório o mRNA não foi mais encontrado. Este achado demonstra que a presença no sangue de mRNA específico da tireóide não está necessariamente relacionada à metástase.

Em 1998, utilizando metodologia de extração de RNA total diferente dos demais, Ringel e cols. (15) detectaram mRNA de Tg em todos os 10 indivíduos normais eutireoideanos testados. Dentre os 87 pacientes com CDT, o mRNA de Tg foi detectado em 26 de 33 pacientes $(79 \%)$ com remanescente em leito tireoideano ou doença metastática confirmada em PCI, ao passo que a $\mathrm{Tg}$ sérica foi detectada somente em 12 destes pacientes $(36 \%)$ durante terapia supressora de TSH. Nos pacientes com PCI negativa, a Tg sérica estava detectável em 2 e o mRNA em 7 pacientes. Neste estudo, a amplificação do mRNA de Tg apresentou maior sensibilidade que a Tg sérica para pesquisa de doença residual, pelo menos durante supressão de TSH. Entretanto, sua especificidade foi inferior. Neste mesmo trabalho, através de técnica de imunocitoquímica, foram demonstradas células com expressão de receptor de TSH e Tg na corrente sangüínea de indivíduos normais, sugerindo que a presença de tireócitos no sangue não estaria relacionada apenas à disseminação hematogênica do carcinoma da tireóide.

Este mesmo grupo (30) desenvolveu um método de RT-PCR quantitativo e amplificou o mRNA de $\mathrm{Tg}$ em todos os 32 voluntários normais. A concentração média encontrada foi de $433 \pm 69$ ng de RNA total tireoideano / litro de sangue, com variação de 26 a $1502 \mathrm{ng} / \mathrm{L}$. Aplicando metodologia semelhante em 107 pacientes com CDT e utilizando o valor de 3 pg de mRNA de Tg / $\mu \mathrm{g}$ RNA de tireóide como ponto de corte, o mRNA de Tg foi encontrado em $38 \%$ dos pacientes sem captação anormal de iodo na PCI, $75 \%$ daqueles com captação em leito tireoideano, $84 \%$ com doença cervical e $94 \%$ com metástase à distância (31).

A amplificação do mRNA do transportador de sódio-iodeto (NIS) também já foi testada (32). O interesse maior no estudo do NIS como marcador tumoral é avaliar se há correlação entre sua expressão e a captação de iodo, tentando explicar a discordância entre Tg sérica e PCI encontrada em alguns pacientes. Entretanto, a amplificação do mRNA do NIS por nested PCR (2 ciclos seguidos de amplificação, utilizando 2 pares de seqüências de oligonucleotídeos iniciadores distintos) mostrou baixa acurácia (sensibilidade de $16,6 \%$ e especificidade de $54 \%$ ), não havendo necessariamente correlação com a captação. A baixa especificidade pode ser explicada, pelo menos em parte, pela expressão deste transportador em tecidos não tireoideanos. Neste mesmo estudo, a sensibilidade e especificidade da amplificação do mRNA da Tg por nested PCR foram de $83 \%$ e $71 \%$ e da Tg sérica 50 e $89 \%$, respectivamente.

A detecção de mRNA de TPO foi novamente estuda (33), desta vez em um grupo maior de 
pacientes: 120 com carcinoma tireoideano, $85 \mathrm{com}$ doença benigna e 54 voluntários normais. Dentre os indivíduos com doença maligna, o mRNA da TPO foi detectado em $70 \%$ daqueles com metástases $(7 / 10)$, sendo que em 3 a Tg sérica foi negativa $(<5 \mathrm{ng} / \mathrm{mL})$. Naqueles sem metástase documentada o mRNA da TPO foi detectado em 36\% (39/110). Nestes, observou-se correlação positiva com a presença de metástase para linfonodo $(\mathrm{p}=0,05)$, estadiamento $(\mathrm{p}=$ $0,01)$ e $\mathrm{Tg}$ elevada $(\mathrm{p}=0,03)$.

A avaliação do mRNA de Tg por RT-PCR quantitativo em crianças com doença tireoideana benigna e maligna não mostrou diferença significativa entre os 2 grupos. Nos pacientes previamente tratados por carcinoma papilífero, o nível de mRNA de $\mathrm{Tg}$ correlacionou-se com a PCI e com a Tg sérica (34).

Apesar destes resultados iniciais promissores, questiona-se atualmente o verdadeiro valor e acurácia da detecção do mRNA de Tg no acompanhamento do CDT. Vários pacientes em aparente remissão clínica (Tg sérica indetectável e PCI negativa) apresentam mRNA circulante detectável (falso-positivo) e alguns pacientes sabidamente com doença metastática apresentam mRNA indetectável (falso-negativo).

A expressão no sangue do mRNA da $\mathrm{Tg}$ por RT-PCR semi-quantitativo (com variação do número de ciclos de 32 a 36) foi comparada entre pacientes submetidos a tireoidectomia total por outra patologia que não $\mathrm{CDT}$ (carcinoma medular de tireóide, carcinoma de laringe e bócio multinodular atóxico) e indivíduos normais (35). Não foi encontrada diferença significativa da expressão do mRNA de Tg entre os 2 grupos. Além disso, o RNA foi detectado tanto na camada de células mononucleares quanto de polimorfonucleares, sugerindo que células sangüíneas talvez possam expressar o mRNA da Tg. Entretanto, deve ser salientado que neste estudo os pacientes tireoidectomizados não foram avaliados com cintilografia da tireóide para avaliar possível remanescente tireoideano pós-operatório.
No estudo por RT-PCR quantitativo com 57 pacientes tireoidectomizados não foi encontrada diferença de expressão do mRNA de Tg entre indivíduos com e sem metástase de CDT, questionando-se a especificidade deste método (36). Entretanto, a metodologia adotada foi diferente (não foi realizado tratamento com DNAse para prevenir amplificação de DNA genômico, e a padronização da curva de concentração foi feita com GAPDH e não com RNA de tireóide).

Diante de resultados tão conflitantes (tabela 3), é difícil avaliar o verdadeiro valor do mRNA de Tg. No entanto, realizando uma análise criteriosa da metodologia utilizada pelos diversos grupos observa-se uma enorme variedade de protocolos, o que certamente justifica a discrepância entre os resultados. Em relação ao processamento da amostra de sangue, observa-se variação quanto a: 1) tipo de tubo em que a amostra é coletada (com heparina, citrato, EDTA ou diretamente no tubo de extração contendo substância estabilizadora de RNA), 2) volume de sangue utilizado $(0,3$ a $10 \mathrm{~mL}), 3)$ separação de camadas celulares por gradiente ou utilização de sangue total, 4) Kit de extração de RNA (6 diferentes kits utilizados) e 5) tratamento ou não do RNA extraído com DNAse (tabela 4). Estudo de determinação de carga viral em pacientes infectados pelo HIV demonstrou variação significativa de acordo com o tubo utilizado: o nível de RNA viral no plasma coletado em tubo contendo EDTA foi, em média, $14 \%$ e $31 \%$ mais elevado que no tubo com citrato e heparina, respectivamente (37). Eszlinger e cols. (38), estudando pacientes com CDT, comparou a eficácia de extração de vários métodos (tubos com citrato ou EDTA, separação ou não de camada mononuclear e processamento imediato, 24 horas ou 48 horas após a coleta) e concluiu que a utilização de tubos com citrato com subseqüente separação da camada mononuclear e extração imediata garantem um melhor resultado. Entretanto, não foi comparada esta metodologia com um dos métodos de extração mais utilizados (amostra de sangue adicionada

Tabela 3. Comparação entre os resultados dos principais artigos publicados.

\begin{tabular}{lcccc}
\hline Autor, ano (ref) & $\begin{array}{c}\text { Detecção nos } \\
\text { controles }\end{array}$ & $\begin{array}{c}\text { Detecção na } \\
\text { doença benigna* }\end{array}$ & $\begin{array}{c}\text { Detecção no CDT } \\
\text { em remissão }\end{array}$ & $\begin{array}{c}\text { Detecção no } \\
\text { CDT metastático }\end{array}$ \\
\hline Ditkoff, 1996 (13) & $0 / 7(0 \%)$ & $0 / 6(0 \%)$ & $7 / 78(9,8 \%)$ & $9 / 9(100 \%)$ \\
Ringel, 1998 (15) & $10 / 10(100 \%)$ & - & $7 / 35(20 \%)$ & $14 / 14(100 \%)$ \\
Biscolla, 2000 (32) & $6 / 6(100 \%)$ & - & $4 / 20(20 \%)$ & $2 / 3(66,6 \%)$ \\
Savagner, 2002 (44) & $10 / 10(100 \%)$ & $12 / 12(100 \%)$ & $3 / 15(18 \%)$ & $10 / 10(100 \%)$ \\
Fugazzola, 2002 (45) & $7 / 7(100 \%)$ & $3 / 3(100 \%)$ & $19 / 25(76 \%)$ & - \\
Denizot, 2003 & $0 / 4(0 \%)$ & - & $0 / 8(0 \%)$ & $1 / 7(14,3 \%)$ \\
Chinnappa, 2004 & $0 / 51(0 \%)$ & $3 / 27(11 \%)$ & $2 / 31(6,4 \%)$ & $8 / 8(100 \%)$ \\
\hline
\end{tabular}

* Doença autoimune ou bócio multinodular. 
diretamente em tubo estéril contendo substância estabilizadora de RNA).

Os diversos estudos também divergem quanto à metodologia de RT-PCR: 1) quantidade de RNA total utilizado para a síntese de cDNA (1,0 ng a 11,5 $\mu \mathrm{g})$, 2) quantidade de cDNA empregada para realização da PCR, 3) seqüência de oligonucleotídeos escolhida, 4) tipo de amplificação (PCR qualitativo, nested, semiquantitativo, quantitativo) e 5 ) número de ciclos (tabela 4).

Com relação ao número de ciclos, Bojunda e cols. (39) compararam 2 métodos com sensibilidades distintas, o primeiro utilizando PCR com 30 ciclos (com capacidade de detectar 50 a 100 células expressando mRNA de $\mathrm{Tg}$ ) e o segundo com 40 ciclos (com capacidade de 20 a 30 células). Foi extraído RNA total de vários tecidos e de sangue de indivíduos com CDT (com e sem metástase), doença benigna tireoideana e voluntários normais. Após 30 ciclos de amplificação, o mRNA de Tg foi encontrado no sangue de 9 dos 13 pacientes $(69,2 \%)$ com metástase. Com aumento para 40 ciclos, observou-se incremento da sensibilidade, detectando em 11 destes 13 pacientes; entretanto, houve perda da especificidade, com detecção do mRNA da $\mathrm{Tg}$ em várias amostras de tecido nãotireoideano, como timo, supra-renal, hipófise, pulmão, testículo e apêndice.

Da mesma forma que se acreditava que a expressão do mRNA do receptor de TSH era exclusiva do tireócito e hoje se sabe que é encontrado também em adipócitos e linfócitos $(40,41)$, pode ser que o mRNA da Tg também seja expresso por outras células, fenômeno denominado de transcrição ilegítima.
Gupta e cols. (42) investigaram a especificidade de diferentes pares de seqüências de oligonucleotídeos iniciadores (primers) em amplificar o mRNA de Tg e do receptor de TSH (TSHR) em sangue de indivíduos normais e em amostra de câncer de tireóide. Para isto foram escolhidos 4 pares de primers de TSHR e 3 pares de $\mathrm{Tg}$ já descritos previamente na literatura $(13,15,43)$. Foi observado que todos os primers de TSHR e de $\mathrm{Tg}$ foram capazes de amplificar os respectivos mRNAs extraídos a partir de tecido. Quando os experimentos foram realizados com RNA extraído a partir de sangue (camada de células mononucleares), somente 1 par de primers de TSHR e 1 de Tg não amplificou. Estes resultados sugerem que células sanguíneas talvez possam expressar estes mRNAs. Entretanto, é provável que o processamento pós-transcripcional (splicing) seja distinto nas células tireoideanas e não-tireoideanas e que a seleção do primer possa determinar maior especificidade ao método.

Splicing alternativo do mRNA de $\mathrm{Tg}$ pode afetar não somente a especificidade, como também a sensibilidade, especialmente se a seqüência de oligonucleotídeos empregada for direcionada para áreas sabidamente de risco de splicing. A possibilidade de resultado falso-negativo decorrente de splicing alternativo foi avaliada por Savagner e cols. (44). Para estimar o risco de erro na medida do mRNA de $\mathrm{Tg}$, foi calculada a percentagem de uma das formas variantes do mRNA, comparando com o total de mRNA de Tg em células tireoideanas circulantes. Cerca de $20 \%$ dos pacientes avaliados apresentaram este splicing alternativo, correspondendo a até $33 \%$ do valor total.

Tabela 4. Diferença da metodologia empregada para amplificação de mRNA de tireoglobulina.

\begin{tabular}{|c|c|}
\hline Variáveis & Diferenças de Protocolo \\
\hline Tubo para coleta de sangue & $\begin{array}{l}\text { Heparinizado } 14,36,48 \text {; contendo citrato } 38 \text {; } \\
\text { EDTA29,33-37,40,46,48; ou diretamente em tubo contendo } \\
\text { substância estabilizadora de RNA } 13,15,31,32,44,45,47\end{array}$ \\
\hline Volume de sangue & $1,032,45$ a $10 \mathrm{ml}^{14,36}$ \\
\hline Preparo do sangue para extração & $\begin{array}{l}\text { Separação por gradiente de camadas } \\
\text { celulares } 14,33,34,36,39,42,48 \text { ou extração a partir de } \\
\text { sangue total } 13,15,30-32,38,44-47\end{array}$ \\
\hline Kit de extração de RNA & $\begin{array}{l}\text { TRIzol14,15,31,32,35,36,42,44,45,48; RNA STAT 6013; PUREscript30,34,46,47; } \\
\text { Rneasy blood33,35,39; QIAmp RNA blood38; PAXgene blood RNA49 }\end{array}$ \\
\hline $\begin{array}{l}\text { Amplificação de DNA genômico } \\
\text { ou RNA }\end{array}$ & $\begin{array}{l}\text { Tratamento do RNA com DNAse; uso de primers em exons } \\
\text { distintos }\end{array}$ \\
\hline Quantidade de RNA & $1,0 \mathrm{ng}^{48}$ a $11,5 \mathrm{mcg}^{38}$ \\
\hline $\begin{array}{l}\text { Seqüência de oligonucleotídeos } \\
\text { iniciadores }\end{array}$ & $\begin{array}{l}\text { Escolha de primers localizados em diversas regiões do } \\
\text { gene de tireoglobulina, englobando ou não áreas } \\
\text { sujeitas a splicing alternativo. }\end{array}$ \\
\hline Tipo de amplificação & $\begin{array}{l}\text { PCR qualitativo 13-15,39,42,45,46; nested PCR } 32,33,48 ; \\
\text { PCR semi-quantitativo } 35 ; \text { PCR quantitativo30,31,34,36,38,44,47,49 }\end{array}$ \\
\hline Número de ciclos & $30^{14,39,42}$ a $35+35^{33}$ \\
\hline
\end{tabular}


Mais recentemente, foram estudados 36 pacientes com CDT em aparente remissão e com anticorpo anti- $\mathrm{Tg}$ negativo (45). Foram dosados $\mathrm{Tg}$ sérica por 2 métodos com sensibilidade de $0,9 \mu \mathrm{g} / \mathrm{L}$ e $0,1 \mu \mathrm{g} / \mathrm{L}$ (Tg altamente sensível), além do mRNA de $\mathrm{Tg}$, antes e após a administração de TSH recombinante. Foi avaliado o grau de concordância entre estes exames e a avaliação clínica (USG cervical, PCI, Tg altamente sensível após TSH recombinante). A Tg com sensibilidade de $0,9 \mu \mathrm{g} / \mathrm{L}$ apresentou concordância de $53 \%$ no basal e 55\% após estimulação com TSH. O RNA concordou com a avaliação clínica em $66 \%$ no basal e pós-estimulação. Neste estudo, as condições da RTPCR foram otimizadas para evitar transcrição ilegítima. Foi primeiramente estabelecida a quantidade de cDNA oriundo de células K562 (células de leucemia mielóide crônica) que não determina amplificação de $\mathrm{Tg}$. Com base neste dado, foi posteriormente feita padronização para as amostras de sangue dos pacientes. Nestas condições, não foi observada amplificação de mRNA de $\mathrm{Tg}$ no paciente com agenesia tireoideana. Desta forma, o emprego de uma metodologia que diminua o risco de interferência da transcrição ilegítima talvez possa ser útil.

Apesar da possibilidade de baixa especificidade por transcrição ilegítima da $\mathrm{Tg}$ ou por variantes de $\mathrm{Tg}$ em células não tireoideanas, não se pode, até o momento, afastar a hipótese de alta sensibilidade do método, diagnosticando precocemente a recidiva. Somente o acompanhamento a longo prazo dos pacientes estudados poderá definir se aqueles com mRNA detectável apresentam maior risco de recorrência tumoral. Nos 28 pacientes com CDT estudados por Grammatopoulos e cols. (46), a identificação de metástases na PCI correlacionou-se melhor com mRNA do que com a $\mathrm{Tg}$ sérica. Cinco destes pacientes foram estudados prospectivamente com coleta de sangue a cada 2 meses. Quatro mantiveram Tg e mRNA de Tg indetectáveis. No outro paciente, o mRNA estava presente apesar da Tg indetectável; no entanto, durante o acompanhamento a Tg sérica elevou-se e a PCI identificou metástases.

Elisei e cols. (47), utilizando metodologia criteriosa (primers selecionados para evitar formas variantes de Tg e tratamento com DNAse para evitar amplificação genômica), estudaram 80 pacientes com CDT e 20 indivíduos normais. Foram encontradas sensibilidade de $82,3 \%$ e especificidade de $24,2 \%$. Os 9 pacientes com RNA detectável, sem outra evidência de doença, foram reavaliados após 4 anos com dosagem de Tg sérica basal e estimulada, que se manteve indetectável. Desta forma, o mRNA não foi capaz de pre- dizer a recorrência tumoral, sugerindo falso-positivo. Deve-se ressaltar, entretanto, o número pequeno de pacientes envolvidos e o curto período de acompanhamento.

Com base nestes resultados conflitantes, a amplificação de mRNAs característicos da tireóide não parece ser, até o momento, superior aos métodos sensíveis de dosagem de $\mathrm{Tg}$ sérica já existentes. No estudo realizado em nosso Serviço foram avaliados 32 pacientes com carcinoma da tireóide. A Tg sérica em supressão e o mRNA de Tg no sangue apresentaram sensibilidade de $75 \%$ e especificidade de $100 \%$ e $61,1 \%$, respectivamente. Nos pacientes em que se detectou o mRNA de $\mathrm{Tg}$ no sangue não foi observado um maior risco de recidiva num período de até 24 meses de acompanhamento, sugerindo resultado falso-positivo.

Desta forma, a aplicabilidade clínica do teste de mRNA de Tg só será possível após padronização de técnica capaz de distinguir a amplificação específica da não específica (transcrição ilegítima). Este esforço é válido, pois o anticorpo anti-Tg está presente em um percentual considerável de pacientes com CDT, limitando a utilização da $\mathrm{Tg}$ sérica como marcador tumoral.

\section{REFERÊNCIAS}

1. Hamming JF, Van de Velde CJ, Goslings BM, Shelfhout LJ, Fleuren GJ, Hermans J. Prognosis and morbidity after total thyroidectomy for papillary and follicular and medullary thyroid cancer. Eur J Cancer Clin Oncol 1989:25:1317-23

2. Mazzaferri EL, Massoll N. Management of papillary and follicular (differentiated) thyroid cancer: new paradigms using recombinant human thyrotropin. EndocrineRelated Cancer 2002;9:227-47.

3. Frasoldati A, Pesenti M, Gallo M, Caroggio A, Salvo D, Valcavi R. Diagnosis of neck recurrence in patients with differentiated thyroid carcinoma. Cancer 2003:97:91-6.

4. Schlumberger M, Baudin E. Serum thyroglobulin determination in the follow-up of patients with differentiated thyroid carcinoma. Eur J Endocrinol 1998; 138:249-52.

5. Spencer CA, LoPresti JS, Fatemi S, Nicoloff JT. Detection of residual and recurrent differentiated thyroid carcinoma by serum thyroglubulin measurement. Thyroid 1999:95:435-41.

6. Girelli ME, De Vido D. Serum thyroglobulin measurements in differentiated thyroid cancer. Biomed Pharmacother 2000;54:330-3.

7. Kumar A, Shah DH, Shrihari U, Dandekar SR, Vijayan U, Sharma SM. Significance of antithyroglobulin antibodies in differentiated thyroid carcinoma. Thyroid 1994;4: 199-202. 
8. Spencer CA, Takeuchi M, Kazarosyan M, Wang CC, Guttler RB, Singer PA, et al. Serum thyroglobulin autoantibodies: prevalence, influence on serum thyroglobulin measurement and prognostic significance in patients with differentiated thyroid carcinoma. J Clin Endocrinol Metab 1998;83:1121-7.

9. Chung J-K, Park YJ, Kim TJ, So Y, Kim S-K, Park DJ, et al. Clinical significance of elevated level of serum antithyroglobulin antibody in patients with differentiated thyroid cancer after thyroid ablation. Clin Endocrinol 2002:57:215-21.

10. Moreno JG, Croce CM, Fischer R, Monne M, Vihko P, Mulholland $S G$, et al. Detection of hematogenous micrometastasis in patients with prostate cancer. Cancer Res 1992;52:6110-2.

11. Burchill AS, Bradbury FM, Smith B, Lewis IJ, Selby P. Neuroblastoma cell detection by reverse transcriptasepolimerase chain reaction (RT-PCR) for tyrosin hydroxylase mRNA. Int J Cancer 1994;54:671-5.

12. Johnson PWM, Burchill SA, Selby PJ. The molecular detection of circulation tumour cells. $\mathrm{Br} \mathbf{J}$ Cancer 1995; 72:268-76

13. Ditkoff BA, Marvin MR, Yemul S, Shi YJ, Chabot J, Feind C, et al. Detection of circulating thyroid cells in peripheral blood. Surgery 1996; 120:959-65

14. Tallini G, Ghossein RA, Emanuel J, Gill J, Kinder B, Dimich $A B$, et al. Detection of thyroglobulin, thyroid peroxidase and RET/PTC 1 mRNA transcripts in the peripheral blood of patients with thyroid disease. J Clin Oncol 1998; 16:1158-66.

15. Ringel MD, Ladenson PW, Levine MA. Molecular diagnosis of residual and recurrent thyroid cancer by amplification of thyroglobulin messenger ribonucleic acid in peripheral blood. J Clin Endocrinol Metab 1998:83:4435-42

16. Baas F, Bikker H, Geurts van Kessel A, Melsert R, Pearson $\mathrm{PL}$, de Vijder JJM, et al. The human thyroglobulin gene: a polymorphic marker localized distal to c-myc on chromosome 8 band q24. Human Gen 1985;69:138-45.

17. Mendive FM, Rivolta CM, Vassart G, Targovnik HM. Genomic organization of the 3' region of the human thyroglobulin gene. Thyroid 1999;9:903-12.

18. Van de Graaf SAR, Ris-Stalpers C, Pauws E, Mendive FM, Targovnik HM, de Vijlder JJM. Up to date with human thyroglobulin. J Endocrinol 2001;170:307-21.

19. Lerman J. lodine components of the blood: circulating thyroglobulin in normal person and in persons with thyroid disease. J Clin Invest 1940; 19:555-9.

20. Van Herle AJ, Uller RP, Matthews NL, Brown J. Radioimmunoassay for measurement of thyroglobulin in human serum. J Clin Invest 1973:52:1320-7.

21. Torréns JI, Burch HB. Serum thyroid measurement - Utility in clinical practice. Endocrinol Metab Clin North Am 2001;30:429-55.

22. Spencer CA. Recoveries cannot be used to authenticate thyroglobulin (Tg) measurements when sera contain Tg autoantibodies. Clin Chem 1996:42:661-3.

23. Preissner CM, O'Kane D, Singh RJ, Morris JC, Grebe SKG. Phantoms in the assay tube: heterophile antibody interferences in serum thyroglobulin assays. J Clin Endocrinol Metab 2003;88:3069-74.
24. Izumi M, Kubo I, Taura M, Yamashita S, Morimoto I, Ohtakara $\mathrm{S}$, et al. Kinetic study of immunoreactive human thyroglobulin. J Clin Endocrinol Metab $1986 ; 62: 410-2$

25. Schlumberger M. Papillary and follicular thyroid carcinoma. N Engl J Med 1998;338:297-306.

26. Schlumberger M, Pacini F. Thyroid tumors. Paris: Éditions Nucléon, 1999. p.317

27. Mattano YZ, Moss TJ, Emerson SG. Sensitive detection of rare circulating neuroblastoma cells by reverse transcriptase-polymerase chain reaction. Cancer Res 1992; $52: 4701-5$.

28. Datta YH, Adams PT, Drobyski WR, Ethier SP, Terry VH, Roth MS. Sensitive detection of occult breast cancer by the reverse-transcriptase-polymerase chain reaction. J Clin Oncol 1994; 12:474-82.

29. Ghossein RA, Scher HI, Gerald WL, Kelly WK, Curley T, Amsterdam A, et al. Detection of circulating tumor cells in patients with localized and metastatic prostatic carcinoma: clinical implications. J Clin Oncol 1995; 13:1195-200.

30. Wingo ST, Ringel MD, Anderson JS, Patel AD, Lukes YD, Djuh Y-Y, et al. Quantitative reverse transcription-PCR of thyroglobulin mRNA in peripheral blood of healthy subjects. Clin Chem 1999;45:785-9.

31. Ringel MD, Balducci-Silano PL, Anderson JS, Spencer $\mathrm{CA}$, Silverman J, Sparling $\mathrm{YH}$, et al. Quantitative reverse transcription-PCR of circulating thyroglobulin messenger ribonucleic acid for monitoring patients with thyroid carcinoma. J Clin Endocrinol Metab 1999;84:4037-42.

32. Biscolla RP, Cerutti JM, Maciel RM. Detection of recurrent thyroid cancer by sensitive nested reverse transcription-polymerase chain reaction of thyroglobulin and sodium/iodide symporter messenger ribonucleic acid transcripts in peripheral blood. J Clin Endocrinol Metab 2000; 85:3623-7.

33. Roddiger SJ, Bojunda J, Klee V, Stanisch M, Renneberg $\mathrm{H}$, Lindhorst $\mathrm{E}$, et al. Detection of thyroid peroxidase mRNA in peripheral blood of patients with malignant and benign thyroid disease. J Mol Endocrinol 2002:29:287-5

34. Fenton C, Anderson JS, Patel AD, Lukes Y, Solomon B, Tuttle $M$, et al. Thyroglobulin messenger ribonucleic acid levels in the peripheral blood of children with benign and malignant thyroid disease. Pediatr Res 2001:49:429-34.

35. Bugalho MJ, Domingues RS, Pinto AC, Garrão A, Catarino AL, Ferreira T, et al. Detection of thyroglobulin mRNA transcripts in peripheral blood individuals with and without thyroid glands: evidence for thyroglobulin expression by blood cells. Eur J Endocrinol 2001;145: 409-13.

36. Takano T, Miyauchi A, Yoshida $\mathrm{H}$, Hasegawa $\mathrm{Y}$, Kuma $\mathrm{k}$, Amino N. Quantitative measurement of thyroglobulin mRNA in peripheral blood of patients after total thyroidectomy. Br J Cancer 2001;85:102-6.

37. Dickover RE, Herman SA, Saddia K, Wafer D, Dillon M, Bryson YJ. Optimization of specimen-handling procedures for accurate quantitation of levels human immunodeficiency virus RNA in plasma by reverse transcriptase PCR. J Clin Microbiol 1998;36:1070-3. 
38. Eszlinger M, Neumann S, Otto L, Paschke R. Thyroglobulin mRNA quantification in the peripheral blood is not a reliable marker for the follow-up of patients with differentiated thyroid cancer. Eur J Endocrinol 2002; 147:575-82.

39. Bojunda J, Röddiger S, Stanisch M, Kusterer K, Kurek R, Renneberg $\mathrm{H}$, et al. Molecular detection of thyroglobulin mRNA transcripts in peripheral blood of patients with thyroid disease by RT-PCR. Br J Cancer 2000;82:1650-5

40. Francis $T$, Burch HB, Cai WY, Lukes Y, Peele M, Carr FE, et al. Lymphocytes express thyrotropin receptor-specific mRNA as detected by the PCR technique. Thyroid $1991 ; 1: 223-8$.

41. Endo T, Ohta K, Haraguchi K, Onaya T. Cloning and functional expression of a thyrotropin receptor CDNA from rat fat cells. J Biological Chem 1995;270:10833-7.

42. Gupta MK, Tagupa L, Areiaga R, Siperstein A, Faiman C, Mehta $A$, et al. Detection of circulating thyroid cancer cells by reverse transcription-PCR for thyroid stimulating hormone receptor and thyroglobulin: the importance of primer selection. Clin Chem 2002;48: 1862-5.

43. Arturi F, Russo D, Giuffrida D, Ippolito A, Perroti N, Vigneri $\mathrm{R}$, et al. Early diagnosis by genetics analysis of differentiated thyroid cancer metastases in small lymph nodes. J Clin Endocrinol Metab 1997;82:1638-41.

44. Savagner F, Rodien P, Reynier P, Rohmer V, Bigorgne J$C$, Malthiery Y. Analysis of Tg transcripts by real-time RTPCR in the blood of thyroid cancer patints. J Clin Endocrinol Metab 2002;87:635-9.
45. Fugazzola L, Mihalich A, Persabi L, Cerutti N, Reina $M$, Vannucchi $G$, et al. Highly sensitive serum thyroglobulin and circulating thyroglobulin mRNA evaluations in the management of patients with differentiated thyroid cancer in apparent remission. J Clin Endocrinol Metab 2002;87:3201-8.

46. Grammatopoulos D, Elliott Y, Smith SC, Brown I, Greive RJ, Hillhouse EW, et al. Measurement of thyroglobulin mRNA in peripheral blood as an adjunctive test for monitoring thyroid cancer. Mol Pathol 2003;56:162-6.

47. Elisei R, Vivaldi A, Agate L, Molinaro E, Nencetti C, Grasso $L$, et al. Low specificity of blood thyroglobulin messenger ribonucleic acid assay prevents its use in the follow-up of differentiated thyroid cancer patients. J Clin Endocrinol Metab 2004;89:33-9.

48. Bellantone R, Lombardi CP, Bossola M, Ferrante A, Princi $\mathrm{P}$, Boscherini $\mathrm{M}$, et al. Validity of thyroglobulin mRNA assay in peripheral blood of postoperative thyroid carcinoma patients in predicting tumor recurrences varies according to the histologic type. Cancer 2001:92:2273-9.

49. Li D, Butt A, Clarke S, Swaminathana R. Real-time quantitative PCR measurement of thyroglobulin mRNA in peripheral blood of thyroid cancer patients and healthy subjects. Ann N Y Acad Sci 2004; 1022:147-51.

\section{Endereço para correspondência:}

Sabrina Mendes Coelho

Rua Potiguara 325/104

22750-290 Rio de Janeiro, RJ

E-mail: sabrinacoelho@globo.com 